http://dx.doi.org/10.12775/szhf.2015.053

\title{
Matyukhina Oleksandra
}

National Aviation University, Kiev, Ukraine

RYBY_MATYUKHINA@MAIL.RU

\section{Filozofia Kanta na Ukrainie. Sylwester Gogocki}

Filozofia Kanta zaczęła rozpowszechniać się na Ukrainie od początku XIX wieku. W 1803 roku w Nikołajewie zostało wydane pierwsze tłumaczenie Prolegomenów Immanuela Kanta na język rosyjski wykonane przez P. Rubana. Górski zauważa, że:

Piotr Łodij, był prawdopodobnie pierwszą osobą, która zapoznała ukraińskie społeczeństwo z twórczością I. Kanta. Idee założyciela niemieckiej filozofii klasycznej na uniwersytecie w Charkowie (1807-1809) rozpowszechniał Ł. Jakob, na Zakarpaciu - W. Dowhowycz ${ }^{1}$.

Jednak największe zasługi w popularyzacji filozofii Kanta na Ukrainie ma niewątpliwie Sylwester Gogocki. To właśnie on po raz pierwszy w historii filozofii ukraińskiej w swoich dziełach zawarł fundamentalną i wszechstronną charakterystykę filozofii I. Kanta.

Sylwester Gogocki (1813-1889) (nazwisko zapisywane również jako Gogotski) to wybitny filozof ukraiński, pedagog. Zasłużony przedstawiciel kijowskiej szkoły teizmu filozoficznego. Autor licznych prac historyczno-fi-

\footnotetext{
${ }^{1}$ Patrz. В. С. Горський, Історія української філософї, Київ 2001, s. 132.
} 
lozoficznych oraz pierwszej na terenie Imperium Rosyjskiego encyklopedii filozoficznej. Jeden z pierwszych historyków filozofii na Ukrainie oraz w całym Imperium Rosyjskim.

Gogocki urodził się w 1813 r. w Kamieńcu Podolskim w rodzinie duchownego. Ukończył Gimnazjum Podolskie. W latach 1833-1837 pobierał nauki w Kijowskiej Akademii Duchownej, która w tym czasie wciąż jeszcze pełniła funkcję jednego z najważniejszych ośrodków myśli filozoficznej na Ukrainie. Dlatego też mówiąc o Gogockim jako o filozofie należy poświęcić nieco uwagi kijowskiej szkole religijno-filozoficznej i jej początkom. Jest ona genetycznie związana z tradycjami filozofowania Rusi Kijowskiej i epoki Odrodzenia. Od XVII w. ukraińska myśl filozoficzna rozwijała się przede wszystkim w Akademii Kijowsko-Mohylańskiej. Jej przedstawiciele - F. Prokopowycz, S. Jaworski, J. Kononowycz-Horbacki, I. Gizel i inni - dążyli do syntezy patrystyki, neoplatonizmu oraz idei filozofów Renesansu ukraińskiego z ideami filozofii zachodnioeuropejskiej. Szczególnie popularna stawała się wówczas nauka R. Descartes'a, B. Spinozy. F. Suarez'a, a następnie Ch. Wolffa. Profesorowie Akademii Kijowsko-Mohylańskiej kwestie teologiczno-filozoficzne traktują z pozycji teizmu, rzadziej deizmu. Idea harmonii wiary i rozumu łączy się u nich z zainteresowaniem filozofią natury, kwestią poznania, wolną wolą człowieka i jego miejscem w świecie. Szczytem osiągnięć myśli filozoficznej na Ukrainie w XVIII w. stała się filozofia H. Skoworody. Pomimo zamknięcia Akademii Kijowsko-Mohylańskiej kijowski teizm filozoficzny wciąż się rozwijał. Jego tradycje były kontynuowane przez Kijowską Akademię Duchowną, utworzoną w 1819 r. na miejscu zamkniętej Akademii Kijowsko-Mohylańskiej. Szczególne znaczenie miała tu działalność biskupa Innocentego, który pełnił funkcje rektora Akademii w latach 1830-1840. Od 1819 do 1849 r. profesorem filozofii był protojerej I. Skworcow. W odróżnieniu od swoich poprzedników, którzy w wykładach opierali się przede wszystkim na filozofii Ch. Wolffa, I. Skworcow popularyzował poglądy przedstawicieli niemieckiej filozofii klasycznej, szczególnie I. Kanta. Od 1836 r. filozofię wykładał również P. Awsieniew, wysoko ceniący idee F. Schellinga oraz jego zwolenników. W tym czasie Akademia Kijowska stała się ośrodkiem kijowskiej filozofii religijnej. Jej przedstawiciele, jak zauważa W. Gorski, dążyli do połączenia idei wybitnych filozofów zachodnioeuropejskich, a przede wszystkim niemieckiej filozofii klasycznej z ukraińską tradycją duchową, w której najważniejszy był neoplatonizm i patrystyka ${ }^{2}$. W tym właśnie okresie studen-

\footnotetext{
${ }^{2}$ Por. tamże, s. 156.
} 
tami akademii byli tacy wybitni przedstawiciele kijowskiej szkoły teizmu filozoficznego jak O. Nowicki, I. Michniewicz, S. Gogocki (w takich warunkach ukształtowały się ich poglądy i pasje filozoficzne).

Gogocki ukończył akademię w 1837 r. ze stopniem magistra i podjął w niej pracę jako wykładowca. Od 1850 do 1886 prowadził wykłady na Uniwersytecie Kijowskim im. św. Włodzimierza. W roku 1850 uzyskał stopień doktora habilitowanego filozofii i filologii klasycznej (praca doktorska pt. Ogląd systemu filozoficznego G. W. F. Hegla). Od roku 1869 wykładał jako profesor na odnowionej katedrze filozofii. Badacze koncepcji S. Gogockiego twierdzą, że na jego poglądy filozoficzne duży wpływ wywarła filozofia G. Hegla. Warto jednak zaznaczyć, że chociaż przywiązywał dużą wagę do idei historycyzmu Hegla, jego stosunku do Idei Absolutnej jako siły twórczej, przejawiającej się w świecie fizycznym i moralnym, odrzucał skrajny heglowski racjonalizm zastępujący to, co indywidualne przez to, co ogólne. Spojrzenie Gogockiego na człowieka i jego świat duchowy jest bliższe poglądom I. Kanta.

Stanowisko filozoficzne S. Gogockiego charakteryzuje się dążeniem do harmonii wiary i wiedzy. A. Abramow pisze, że:

Gogocki przez cały czas deklarował swój teistyczny światopogląd, starając się w miarę możliwości nie wychodzić poza ramy ortodoksyjnego prawosławia. Jego myśl wciąż kierowała się w stronę takiej percepcji świata, w której Boga postrzegano jako umysł doskonały, będący natchnieniem zarówno dla koncepcji filozoficznych Schellinga, jak i Hegla, którzy kontynuowali i dopełniali naukę Kanta pod tym względem, że u nich idea Istoty Absolutnej powstaje nie tylko na podstawie wyłącznego żądania natury moralnej, lecz znacznie szerszej i bardziej globalnie ${ }^{3}$.

S. Gogockiemu przyszło pracować w trudnych czasach. W roku 1850 kiedy to wstąpił na Uniwersytet im. św. Włodzimierza ukazem Imperatora Nikołaja I zostało zabronione wykładanie filozofii na uniwersytetach świeckich. Każda filozofia z punktu widzenia rosyjskiego caratu była uważana za zbyt wolnomyślicielską. Uważano, że jej główna wada polega na tym, iż kształtuje ona swobodę myślenia, a więc umiejętność niepożądaną u poddanych Imperium Rosyjskiego. Koncepcja „prawosławia, samowładztwa i ludowości” przewidywała wyłącznie jednomyślność i pokorę. We wszelkich przejawach wolnego myślenia - w sztuce, nauce, filozofii, szczególnie w ocenie zjawisk życia społecznego carat dostrzegał niebezpieczeństwo protestu, zalążek nastrojów rewolucyjnych. Pewne elementy filozofii próbowano więc przekazy-

\footnotetext{
${ }^{3}$ История русской философии, Москва 2001, s. 293.
} 
wać podczas nauczania logiki i pedagogiki. S. Gogocki za wszelką cenę starał się zachować kulturę wykładania filozofii na Uniwersytecie Kijowskim. Już współcześni mu autorzy zauważyli, że na wykładach z pedagogiki dużo uwagi poświęcał historii filozofii. Większość prac, napisanych przez Gogockiego, to materiały dotyczące historii filozofii: Krytyczne spojrzenie na filozofię I. Kanta (1847), O charakterze filozofii wieków średnich (1849), Ogląd systemu filozoficznego I. Kanta (1860), Wstęp do filozofii (1871), Filozofia XVII i XVIII w. w porównaniu z filozofia XIX w. i ich wpływ na oświatę (1878-1884), Słownik filozoficzny (1876). W jego pracach historyczno-filozoficznych przejawia się silny wpływ filozofii Hegla. Gogocki w pracy Wprowadzenie do historii filozofii pisze:

Historia filozofii powinna wyrażać istotną cechę rozwoju, odróżniającą życie wewnętrzne istoty myślącej. Podstawa idei rozwoju, charakterystycznego dla strony duchowej, powinna wyrażać się w filozofii nie tylko jako wynik rozwoju jej kierunków, lecz jako stopniowy rozwój połączenia systemu wiedzy i samoświadomości.

Pojawienie się nowych kierunków w filozofii Gogocki tłumaczy wewnętrzną naturalną kolejnością rozwoju jej podstaw i kierunków:

Każda nowa doktryna filozoficzna pojawia się w sposób obiektywny jako potrzeba poprawienia lub uzupełnienia poprzedniej, bądź też w przypadku konieczności stworzenia całkowicie nowych podstaw i budowanych na nich koncepcji w stosunku do epok wcześniejszych ${ }^{5}$.

Gogocki stosuje pojęcie "podstawowego pytania filozofii” i akcentuje, że nowe nurty filozoficzne pojawiają się wtedy, gdy staje się oczywiste, iż dotychczasowe odpowiedzi są niepełne lub błędne. Podstawowym pytaniem filozofii według myśliciela jest kwestia relacji przedmiotu i podmiotu poznającego.

„Krótko mówiąc, problem polega na tym, że wiedza, podobnie jak życie zakłada istnienie jakiegoś przedmiotu lub materiału i zasady, który je kształtuje. Jeśli więc filozofia w przeważającej swej części jest nauką wiedzy, to do jej zadań należy wyjaśnienie, jakie relacje zachodzą pomiędzy nimi; w zależności od tego, w jaki sposób filozofia tłumaczy te relacje, pojawiają się określone kierunki filozoficzne ${ }^{6}$.

\footnotetext{
${ }^{4}$ С. Гогоцкий, Введение в историю философии, Киев 1871, s. 8.

${ }^{5}$ С. Гогоцкий, Философия XVII и XVIII веков в сравнении с философиею XIX века и отношение той и другой к образованию, Киев 1878, s. 4.

${ }^{6}$ Tamże, s. 5.
} 
Prace Gogockiego stanowią szkołę filozoficznej prezentacji osiągnięć filozofów poprzednich epok. Ocenia ich krytycznie, na ich poglądy patrzy przez pryzmat własnych przekonań filozoficznych, podkreślając aspekty najbardziej znaczące z jego punktu widzenia i opisując ich filozofię oraz sposób rozwiązywania różnych problemów filozoficznych jako metodę filozofowania.

Jedną z najdonioślejszych prac napisanych przez Gogockiego jest Leksykon filozoficzny w czterech tomach (1857-1873). Była to pierwsza encyklopedyczna praca filozoficzna, która powstała w Imperium Rosyjskim. W warunkach, gdy wykładanie filozofii zostało całkowicie zabronione, Leksykon pomagał zachować wiedzę o filozofii na odpowiednim poziomie. D. Czyżewski w Zarysie historii filozofii na Ukrainie pisze między innymi, że nawet jeszcze w jego czasach Leksykon Gogockiego pozostaje wciąż bardzo ważną pozycją. W momencie zaś, w którym został stworzony, a nawet później był dziełem o najgłębszej treści, najpełniej opisującym filozoficzne problemy, wyróżniającym się oryginalnością poglądów na temat procesów historyczno-filozoficznych. Był jedynym tego rodzaju dziełem na obszarze Imperium Rosyjskiego. Dlatego też Leksykon filozoficzny S. Gogockiego, bez względu na różne opinie współczesnych mu autorów, od pozytywnych po negatywne (ze strony materialistów), wywarł ogromny wpływ na rozwój filozofii zarówno na Ukrainie, jak i w Rosji. We wstępie do wydania Gogockiego A. Szewcow podkreśla:

Słowniki się nie starzeją. Odzwierciedlają one drogę, którą przeszliśmy, by dojść do miejsca, w którym widzimy siebie, kiedy odwracamy swoje spojrzenie od świata zewnętrznego i zaglądamy w głąb siebie. Słowniki - to narzędzie całych narodów służące poznaniu samych siebie, to zaś jest droga, którą możemy podążać, by uwolnić się z pułapek ideologicznych, w które wpadamy w pogoni za modą lub postępem. Bez Leksykonu filozoficznego Sylwestra Gogockiego filozofia rosyjska nigdy nie byłaby pełna ani samodzielna pośród innych filozofii światowych ${ }^{7}$.

I należy powiedzieć, że Leksykon filozoficzny miał olbrzymie znaczenie dla rozwoju filozofii ukraińskiej Przez długi czas było to właściwie jedyne dostępne wydanie encyklopedyczne $\mathrm{z}$ dziedziny filozofii w języku rosyjskim. Leksykon popularyzował poglądy takich przedstawicieli niemieckiej filozofii klasycznej, jak: I. Kant i G. W. F. Hegel. Gogocki, wychodząc z założeń teizmu filozoficznego, szereg problemów filozofii przedstawia nawiązując do kon-

${ }^{7}$ А. Шевцов, Сильвестр Сильвестрович Гогоикий, [w:] С. С. Гогоцкий, Философский словарь, Санкт-Петербург 2009, s. 10. 
cepcji I. Kanta i G. Hegla, chociaż nie zgadza się z niektórymi ich twierdzeniami, jak np. z rozbieżnością pomiędzy dziedziną myślenia a istotą rzeczy, odrębnością intelektu i rozumu u Kanta oraz z koncepcją panlogizmu Hegla oraz przewartościowaniem przez niego metody dialektycznej.

Wiele haseł w Leksykonie filozoficznym odnosi się do koncepcji I. Kanta. Duża część filozoficznych dzieł S. Gogockiego poświęcona jest prezentacji filozofii I. Kanta. Przedstawiając filozofię Kanta, Gogocki wyróżnia interesujące go problemy filozoficzne i widzi w podejściu Kantowskim możliwość ich rozwiązania. Chociaż Gogocki w wielu aspektach uważany jest za kontynuatora filozofii G. W. F. Hegla, to bardzo często filozofię Hegla porównuje z filozofią Kanta. W jaki sposób Hegel rozwiązuje poruszone przez niego kwestie? Na ile kwestie, które on (Gogocki) uważa za najważniejsze w filozofii, zostały przeanalizowane przez Hegla dokładniej niż przez Kanta i które z odpowiedzi Hegla są bardziej satysfakcjonujące? Biorąc zatem pod uwagę fakt, iż Gogocki uważał, że filozofia Kanta miała decydujące znaczenie w rozwoju filozofii XIX w., przyjrzymy się dokładniej osobliwościom jego podejścia do filozofii Kanta. W swoich pracach Krytyczne spojrzenie na filozofię I. Kanta (1847), Wprowadzenie do historii filozofii (1871), Leksykon filozoficz$n y$ (w czterech tomach, 1857-1873), Filozofia XVII i XVIII w. w porównaniu $z$ filozofia XIX w. i ich wplyw na oświatę (1878-1884) filozof podkreśla wyjątkowe miejsce I. Kanta w rozwoju filozofii, zauważa, że rezultatem i owocem krytycznej filozofii Kanta jest pojawienie się niemieckiego idealizmu.

Rozpatrując krytyczną filozofię I. Kanta (1724-1804) jako etap przejściowy pomiędzy okresem wcześniejszym a filozofią XIX wieku, należy przede wszystkim zwrócić uwagę na fakt, że filozofia Kanta rzeczywiście miała takie przejściowe znaczenie i że we współczesnym mu świecie nie istniał żaden kierunek filozoficzny, nie było żadnego dzieła filozoficznego, które mogłyby choćby w niewielkim stopniu równać się pod względem rozległości przedstawienia problemów filozoficznych z jego filozofią ${ }^{8}$.

Filozofia przed Kantem (Gogocki nazywa ją kartezjańsko-wolffiańską) oddziela „wyższy byt absolutny” od poznawanej natury. Gogocki podkreśla, że sama wiedza rozumiana jest w sposób dogmatyczny, bez analizy samego procesu poznania. Sensualiści natomiast łączą proces poznania z odczuciami. Gogocki twierdzi, że Descartes, sensualiści i Ch. Wolff nie mogli w sposób zadowalający wyjaśnić relacji pomiędzy podmiotem a przedmiotem.

${ }^{8}$ С. Гогоцкий, Философия XVII и XVII веков в сравнении с философиею XIX века и отномение той и другой к образованию, Киев 1878, s. 122. 
Kant wystąpił z krytyką takiego podejścia, uważał bowiem, że nie można mówić o procesie poznania wyłącznie na podstawie wyobrażeń. Kant poddał krytyce niedoskonałości wcześniejszych założeń filozofii, w swoich rozważaniach wskazał na jej błędy. Analizując filozofię Kanta, Gogocki podkreślał, że szuka przede wszystkim odpowiedzi na pytanie, jaka wiedza jest dostępna dla człowieka. Najważniejszym pytaniem Krytyki czystego rozumu jest według Kanta - „...Na jakiej podstawie przypisujemy podmiotowi predykat, który nie jest bezpośrednio z nim związany i nie wynika z jego obserwacji?" $\mathrm{Za}$ równo w „Leksykonie filozoficznym”, jak i w dziele Filozofia XVII i XVIII $w$. $w$ porównaniu $z$ filozofia XIX w. $i$ ich wpływ na oświatę szczegółowo analizowana jest koncepcja Kanta na temat poznania. Jako jeden z pierwszych ukraińskich filozofów Gogocki dogłębnie, krok po kroku analizuje i wyjaśnia główne założenia filozofii Kanta, stosowane przez niego pojęcia i terminy. Są one również zawarte jako oddzielne hasła w Leksykonie filozoficznym. Zasługą Kanta, jak twierdzi Gogocki, było oddzielenie intelektu, który odnosi się tylko do zjawisk i rozumu, który jest skierowany w stronę wartości absolutnych. Przedstawił on nowy pogląd na istotę procesu poznania. To Kant jako pierwszy, podkreślał uczony, wyraźnie rozdzielił w naszej aktywności poznawczej element wyprzedzający wszelkie doświadczenie od elementu zmysłowego $^{10}$. Wysoka ocena filozofii Kanta nie przeszkadzała jednak Gogockiemu negatywnie oceniać takich koncepcji, jak oddzielenie pierwiastka myślącego od istoty rzeczy, sprzeczności pojęcia zjawiska i pierwiastka myślącego ${ }^{11}$. Twierdzenia Kanta budziły coraz to nowe pytania, które spowodowały rozwój niemieckiego idealizmu obiektywnego, poszukiwanie odpowiedzi na postawione i nie rozwiązane pytania.

Gogocki jako jeden z pierwszych uczonych na Ukrainie podaje w Leksykonie filozoficznym biografię Kanta. Przedstawia ją w sposób charakterystyczny dla filozofii ukraińskiej, a mianowicie podkreśla jedność filozofii, szczególnie filozofii moralnej oraz sposobu życia, moralnej postawy Kanta. Charakteryzuje Kanta nie tylko jako filozofa, ale również jako człowieka. Już ten fakt świadczy o szczególnym stosunku Gogockiego do etycznych aspektów filozofii Kanta. W biografii Kanta Gogocki porusza niezwykle ważny dla siebie problem stosunku wolności myślenia oraz wolności społecznej. Pisze: „Kant zawsze był obrońcą wolności myślenia, jednak bardzo poważnie traktował

\footnotetext{
${ }^{9}$ Por. С. Гогоцкий, Философский лексикон, Киев 1866, s. 43.

10 Tamże, s. 86.

11 Tamże, s. 86.
} 
i wypełniał swoje obowiązki, nie znosił nadmiernej skłonności do wyróżniania się, oryginalności lub tak zwanej nieumiarkowanej wolności"12. Gogocki przedstawia tutaj własne rozumienie wolności myślenia oraz wolności społecznej. Zdawał sobie bowiem sprawę, że bez wolności myślenia niemożliwy jest rozwój nauki, kultury i państwa w ogóle. Broniąc jednocześnie konieczności i znaczenia wolności myślenia, uważa, że w życiu społecznym najważniejsze jest sumienne wypełnianie własnych obowiązków oraz przestrzeganie prawa.

Filozofia Kanta stała się dla Gogockiego podstawą rozwoju jego koncepcji teizmu filozoficznego. Myśliciel podkreśla teistyczne rozumienie Boga przez Kanta, uważa filozofię Kanta, a szczególnie jego Krytykę czystego rozumu za podstawę prawidłowego teizmu. Podkreśla, że Kant opowiada się za teistyczną koncepcją Boga jako istoty moralnie doskonałej i poprzez tę doskonałość odpowiadającej naturze moralnej człowieka.

Wraz z uznaniem natury człowieka jako najwyższego celu w życiu, wszystkich jego procesów i ich rozwoju w czasie, możemy mówić o początkach teizmu prawidłowego, tzn. znalezienia takiej istoty najwyższej, która posiadać będzie wszystkie moralne cechy, konieczne do zrealizowania celów świata. Kant pokazuje, jakie cechy istoty boskiej przejawiają się poprzez takie rozumienie teleologii moralnej. Jeżeli celem całego nurtu życia jest myślący człowiek jako istota moralna i wcielenie ideałów moralnych, to istota Boska powinna być wszechobecna i pełna mądrości, wszechmogąca, dobra i praworządna; wyłącznie takie cechy moralne pozwolą istocie wyższej lub boskiej nie tylko podporządkować sobie wszystkie siły natury, ale także skierować je $\mathrm{w}$ stronę rozumnych celów, wyższego moralnego przeznaczenia świata i oddawać sprawiedliwość zgodnie z postępowaniem każdego człowieka lub odpowiednio do swobodnego zaangażowania przezeń sił13.

W teizmie Gogockiego znaczące miejsce zajmuje problem doskonalenia moralnego i rozwoju człowieka. Podstawę moralnego życia człowieka, jego wiedzy widzi on nie tylko $\mathrm{w}$ wierze, ale również $\mathrm{w}$ wiedzy. Uświadomienie sobie „różnicy pomiędzy naturą a życiem moralnym” Gogocki uważa za jedną z najważniejszych kwestii dla człowieka. A w znalezieniu odpowiedzi na to pytanie może mu pomóc filozofia. Dlatego za najbardziej wartościową w filozofii Kanta Gogocki uważał naukę o moralności. Za szczególną zasługę Kan-

\footnotetext{
12 Tamże, s. 46.

${ }^{13}$ С. Гогоцкий, Философия XVII и XVIII веков в сравнении с философиею XIX века и отномение той и другой к образованию, Киев 1878, s. 166.
} 
ta uznawał jego zrozumienie natury moralnej oraz głęboki szacunek wobec prawd nadprzyrodzonych.

Pojęcie Kanta o naturze moralnej, o wielkości prawa moralnego jest jednym $\mathrm{z}$ najbardziej szlachetnych i pocieszających zjawisk w historii filozofii, szczególnie w wieku XVIII, w epoce, w której w nauce o moralności przeważały pierwiastki uczuciowe i egoistyczne ${ }^{14}$.

Dlatego też szczególnie cenił Kanta Krytykę władzy sądzenia, rozprawę, $\mathrm{w}$ której filozof uzasadnia swobodę rozwoju ducha zgodnie $\mathrm{z}$ autonomicznie wybranymi celami, a nie w wyniku nieuchronnego oddziaływania przyczynowości. Powołując się na poglądy Kanta, widzi on w wierze, moralności i dobrowolnie podjętych zobowiązaniach, podstawę godności człowieka jako osobowości. W zamieszczonym w Stowniku filozoficznym haśle „natura” Gogocki pisze:

Natura tworzy świat, w którym bez względu na różnorodność jego stworzeń, począwszy od połączenia molekuł, aż do żywego organizmu wszystko podporządkowane jest wyłącznie ślepemu i bezwarunkowemu prawu związku przyczynowego zjawisk i określane jest wyłącznie przez działanie czegoś innego oraz poprzez wzajemny wpływ jednych rzeczy na drugie: jak więc w sferze życia istoty myślącej - w rozwoju jej świadomego życia psychicznego, w przejawach prawa, moralności, sztuki itd. przyczynowy bieg zjawisk ożywiany jest jeszcze wyznaczonym przez nią celem - jej własną świadomością i doskonaleniem samowyrażania się [...] Podsumowując, należy zaznaczyć, iż dokładne i uzasadnione uświadomienie sobie różnicy pomiędzy naturą a życiem moralnym stanowi najgłębszy i stały przedmiot nauki nie tylko w ogólnym tego słowa znaczeniu, lecz również całego życia. To właśnie prawidłowe rozwiązanie tej kwestii z wykorzystaniem wiedzy, przekonań i życia, określa godność człowieka ${ }^{15}$.

W tym względzie kontynuuje on antropologiczną linię rozwoju ukraińskiej filozofii. Ukraińska filozofia od początku charakteryzuje się zainteresowaniem problemami człowieka, jego wolności i szczęścia. Gogocki wykładając, tłumacząc i wyjaśniając w swoich pracach filozofię Kanta wzbogaca filozofię ukraińską o osiągnięcia niemieckiej filozofii klasycznej, metodologię rozwiązywania problemów filozoficznych, język filozoficzny. To właśnie prace Gogockiego, które używane były jako podręczniki nie tylko na uniwersyte-

\footnotetext{
${ }^{14}$ С. Гогоцкий, Философский лексикон, Киев 1866, s. 186.

${ }^{15}$ С. Гогоцкий, Философский словарь или краткое объяснение философских и других научных выражений, встречающихся в истории философии, Киев 1876, s. 82-83.
} 
cie w Kijowie, ale również w innych uniwersytetach Rosji, w pewnym stopniu wpłynęły na kształtowanie się filozofii XIX i początku XX wieku. Stosunek Gockiego do Kanta wywarł więc istotny wpływ na rozwój filozofii na Ukrainie i w Rosji.

\section{Bibliografia}

Гогоцкий С., Введение в историю философии, Киев 1871.

Гогоцкий С., Философия XVII и XVII веков в сравнении с философиею XIX века и отночение той и другой к образованию, Киев 1878.

Гогоцкий С., Философский тексикон, Киев 1866.

Гогоцкий С., Философский словарь или краткое объяснение философских и других научных выражений, встречающихся в истории философии, Киев 1876. Горський В. С., Історія української філособії, Київ 2001.

Зеньковский В. В., История русской философии, Москва 2001.

Шевцов А., Сильвестр Сильвестрович Гогоикий, [w:] С. С. Гогоцкий, Философский словарь, Санкт-Петербург 2009.

\section{Abstract \\ The Philosophy of Kant in Ukraine. Sylwester Gogocki}

The article is devoted to the S. Gogotskomu. outstanding Ukrainian philosopher. Proceedings Gogotskogo played a crucial role in spreading the philosophy of I. Kant in Ukraine.

Key words: Ukrainian philosophy, Kant, idealism, philosophical theism, Sylwester Gogocki 